\title{
Megalith quarries for Stonehenge's bluestones
}

Mike Parker Pearson ${ }^{1, *}$, Josh Pollard ${ }^{2}$, Colin Richards ${ }^{3}$, Kate Welham $^{4}$, Chris Casswell ${ }^{5}$, Charles French ${ }^{6}$, Duncan Schlee ${ }^{7}$, Dave Shaw ${ }^{8}$, Ellen Simmons ${ }^{9}$, Adam Stanford ${ }^{10}$, Richard Bevins ${ }^{11} \&$ Rob Ixer $^{1}$

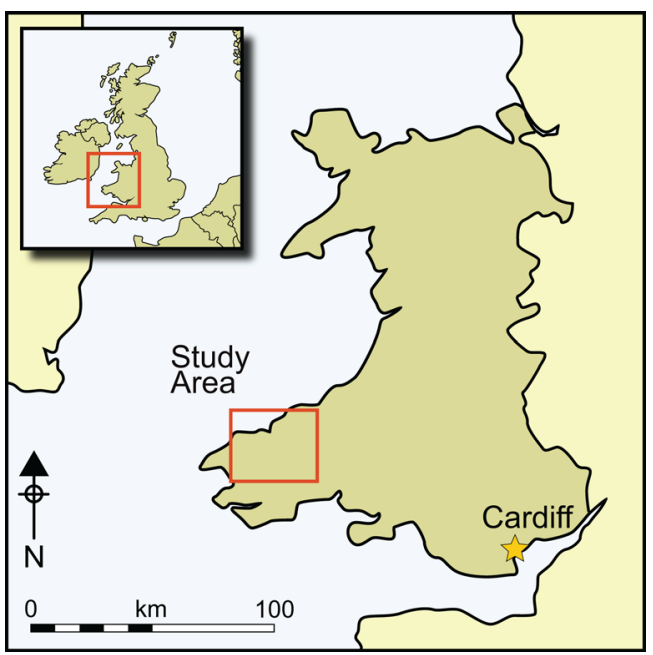

Geologists and archaeologists have long known that the bluestones of Stonehenge came from the Preseli Hills of west Wales, 230km away, but only recently have some of their exact geological sources been identified. Two of these quarries-Carn Goedog and Craig Rhos-yfelin-have now been excavated to reveal evidence of megalith quarrying around $3000 \mathrm{BC}$ - the same period as the first stage of the construction of Stonehenge. The authors present evidence for the extraction of the stone pillars and consider how they were transported, including the possibility that they were erected in a temporary monument close to the quarries, before completing their journey to Stonehenge.

Keywords: Britain, Preseli Hills, Stonehenge, Neolithic, bluestones, dolerite, megaliths, prehistoric quarrying

1 Institute of Archaeology, University College London, 31-34 Gordon Square, London WC1H OPY, UK

2 Department of Archaeology, University of Southampton, Avenue Campus, Southampton SO17 1BF, UK

3 Archaeology Institute, University of the Highlands \& Islands, East Road, Kirkwall, Orkney KW15 1LX, UK

4 Department of Archaeology, Anthropology \& Forensic Science, Talbot Campus, Bournemouth University, Bournemouth BH12 5BB, UK

5 DigVentures Ltd, 20 Jerusalem Passage, Clerkenwell, London EC1V 4JP, UK

6 Department of Archaeology, University of Cambridge, Downing Street, Cambridge CB2 3DZ, UK

7 Pantycelyn, Twynllanan, Llanddeusant, Llangadog, Carmarthenshire SA19 9SP, UK

8 Allen Archaeology Ltd, Whisby Lodge, Hillcroft Business Park, Whisby Road, Lincoln LN6 3QL, UK

9 Department of Archaeology, University of Sheffield, 10-16 Regent Street, Sheffeld S1 3NJ, UK

10 Aerial-Cam Ltd, Vineyard House, Upper Hook Road, Upton upon Severn, Worcestershire WR8 OSA, UK

11 National Museum of Wales, Cathays Park, Cardiff CF10 3NP, UK

* Author for correspondence (Email: m.parker-pearson@ucl.ac.uk)

(c) Antiquity Publications Ltd, 2019

ANTIQUITY 93367 (2019): 45-62 


\section{Introduction}

Geologists have long known that the builders of Stonehenge made use of two main types of stone: a silcrete, known as 'sarsen', was used for the large trilithons, sarsen circle and other monoliths, and a variety of 'bluestones' — used for the smaller standing stones-were erected in an inner 'horseshoe' and an outer circle. Of these 43 bluestone pillars, 27 are of spotted dolerite, known as 'preselite' - an igneous blue-green rock characteristically speckled with ovate patches of pale-coloured secondary minerals. This can be provenanced in Britain only to the Preseli Hills (Mynydd Preseli) in north Pembrokeshire, west Wales-approximately $230 \mathrm{~km}$ from Salisbury Plain (Figure 1).

Stonehenge's spotted dolerite was once thought to have come from Carn Menyn, the largest dolerite outcrop in the Preseli Hills (Thomas 1923). A reassessment of sampled bluestones from Stonehenge, however, identified the outcrop of Carn Goedog as a closer chemical match (Williams-Thorpe et al. 2006). Recent geochemical analysis has revealed two main groups of Stonehenge spotted dolerite, the larger of which (stones 33, 37, 49, $65,67)$ matches most closely with Carn Goedog (Bevins et al. 2013). The second group (stones $34,42,43,61$ ) has not yet been provenanced to a specific Preseli outcrop, but may derive from Carn Goedog, or from nearby outcrops, such as Carn Breseb or Carn Gyfrwy.

Geological characterisation of other types of bluestone present at Stonehenge has identified three further sources (Figure 2). One of these is an outcrop of unspotted dolerite at Cerrigmarchogion and Craig Talfynydd, on the Preseli ridge west of Carn Goedog (Bevins et al. 2013). Another source — of "rhyolite with fabric" (Ixer \& Bevins 2011: 28)—is Craig Rhos-y-felin, an outcrop in the Brynberian tributary of the River Nevern (Ixer \& Bevins 2011; Parker Pearson et al. 2015). The fourth source—of Lower Palaeozoic sandstone—is located in sedimentary beds north of the Preseli hills (Ixer et al. 2017). Other Stonehenge bluestones, notably volcanic tuffs, remain to be sourced, but are also thought to originate in the Preseli area (Ixer et al. 2015; Ixer \& Bevins 2016). Finally, Stonehenge's sandstone 'Altar Stone' is now believed to derive from Lower Old Red Sandstone strata of the Senni Formation (and not from the Cosheston Group around Milford Haven, contra Atkinson (1956: 46)), so it could originate from rocks farther east, at some distance from the bluestone sources, in an area such as the Brecon Beacons (Ixer \& Turner 2006; Ixer et al. 2017).

The geological and archaeological evidence from Carn Goedog, and the results from Craig Rhos-y-felin (Ixer \& Bevins 2011; Parker Pearson et al. 2015), have firmly identified Stonehenge sources and Neolithic megalith-quarrying at those outcrops. Collectively, this research conclusively invalidates the misconception that Pliocene or Pleistocene glaciers may have transported the bluestones to Salisbury Plain (e.g. Kellaway 1971; Williams-Thorpe et al. 1997). The dating of quarrying activity at both Preseli outcrops puts the extraction of the megaliths within two or three centuries of the first erection of the bluestones at Stonehenge stage 1 (3000-2920 cal BC; Darvill et al. 2012a).

\section{Investigating megalith-quarrying at Carn Goedog}

In 2014-2016, we carried out archaeological excavations at Carn Goedog to identify and investigate evidence for prehistoric human activity, such as the extraction of stone pillars

(C) Antiquity Publications Ltd, 2019 


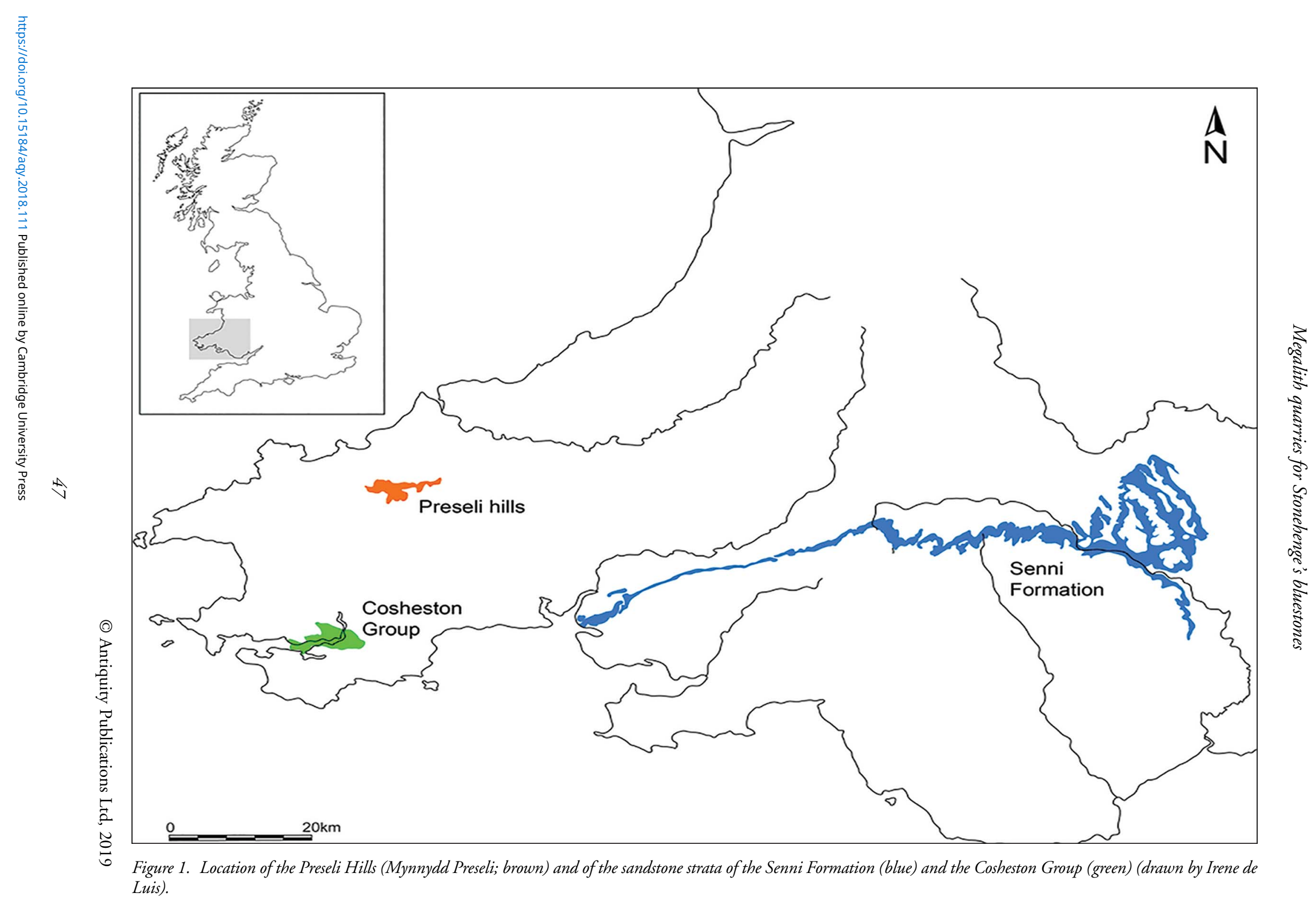

Research 


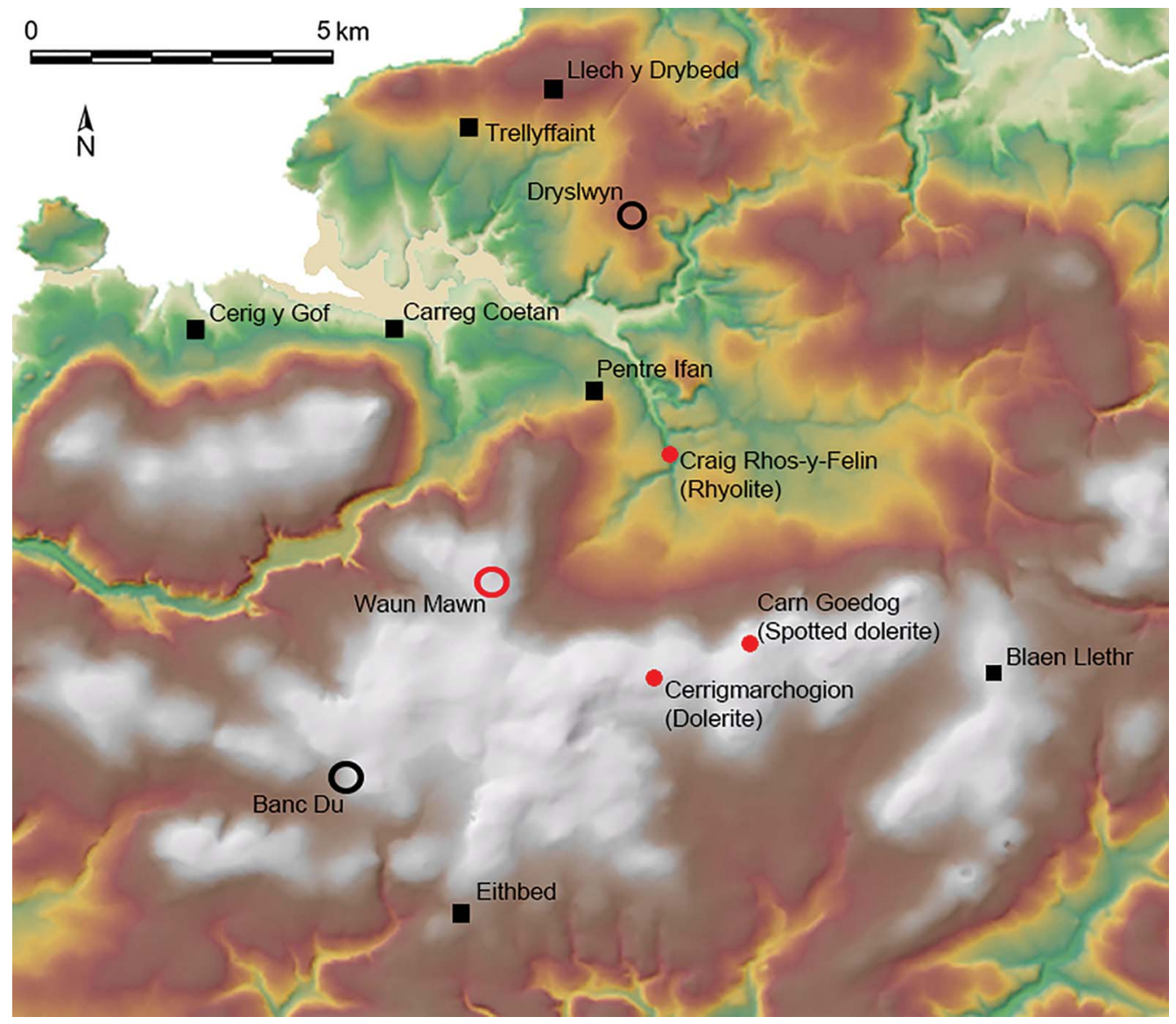

Figure 2. Locations of the bluestone sources of Carn Goedog (spotted dolerite), Craig Rhos-y-felin (rhyolite) and Cerrigmarchogion (unspotted dolerite). The locations of the former stone circle of Waun Mawn, the Neolithic causewayed enclosure of Banc Du and the palisaded enclosure of Dryslwyn, and Early Neolithic portal tombs (black squares) are also shown.

from the outcrop. Scree spreads on the north, east and west sides of the outcrop inhibit access to the jointed formations of natural pillars. Only Carn Goedog's south side is easily accessible —as evidenced by surface traces of post-medieval quarrying. Cylindrical drill-holes in the surfaces of some of the quarried blocks discarded at the foot of the outcrop indicate that this quarrying was carried out using the 'plug-and-feather' technique, using metal wedges. A worn trade token from beneath one of the quarried blocks dates this activity to $c$. AD 1800 .

Test trenching in 2014 along Carn Goedog's southern edge revealed evidence for human activity dating from various periods, ranging from recent centuries (trench 3) back into prehistory (trench 2; Table 1). Trench 1 was positioned at the base of that part of the outcrop just beyond the eastern edge of the early modern quarrying debris. It thus offered the potential for the survival of evidence of prehistoric quarrying unmodified by the later activity (Figure 3).

The outcrop here comprises some of the most impressive natural pillars not only within Carn Goedog, but amongst all of Preseli's spotted dolerite outcrops; some in situ examples at (C) Antiquity Publications Ltd, 2019 
Table 1. Radiocarbon dates from Carn Goedog. Calibrated dates are given at 95.4\% probability using OxCal 4.3 (Bronk Ramsey 2009; Bronk Ramsey \& Lee 2013).

Context Context type Date cal BC/AD Date BP Sample number Material

\section{Deposits above platform}

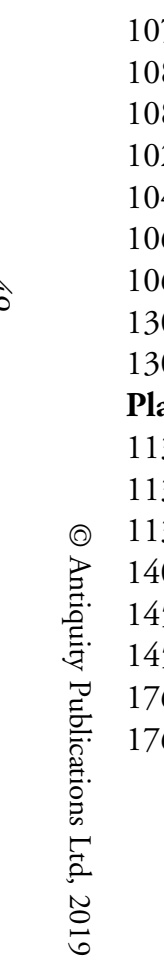

Deposit above north hearth

North hearth

North hearth

South hearth

Pit fill cutting central hearth

Central hearth

Central hearth

Sediment above platform

Sediment above platform

Platform sediment

Platform sediment

Platform sediment

Platform sediment under 130

Platform sediment

Platform sediment

Platform sediment

Platform sediment

$\begin{array}{cccl}\text { AD 1520-1800 } & 261 \pm 24 & \text { OxA-31817 } & \text { Roundwood } \\ \text { AD 1010-1160 } & 963 \pm 24 & \text { OxA-31818 } & \text { Roundwood } \\ \text { AD 1220-1280 } & 767 \pm 25 & \text { OxA-31819 } & \text { Roundwood } \\ \text { AD 250-420 } & 1692 \pm 29 & \text { OxA-31959 } & \text { Roundwood } \\ \text { AD 1520-1800 } & 267 \pm 23 & \text { OxA-31825 } & \text { Roundwood } \\ 7190-6840 \text { BC } & 8091 \pm 38 & \text { OxA-31823 } & \text { Wood } \\ 2890-2630 \text { BC } & 4164 \pm 30 & \text { OxA-31824 } & \text { Wood } \\ \text { 6760-6530 BC } & 7815 \pm 37 & \text { OxA-35157 } & \text { Roundwood } \\ \text { AD 1520-Modern } & 252 \pm 28 & \text { OxA-35397 } & \text { Roundwood } \\ & & & \\ 3350-3090 \text { BC } & 4502 \pm 31 & \text { OxA-31820* } & \text { Roundwood } \\ 3350-3030 \text { BC } & 4490 \pm 31 & \text { OxA-31821* } & \text { Roundwood } \\ 3350-3040 \text { BC } & 4491 \pm 31 & \text { OxA31822 } & \text { Roundwood } \\ 3660-3520 \text { BC } & 4810 \pm 34 & \text { OxA-35398 } & \text { Roundwood } \\ 3020-2880 \text { BC } & 4316 \pm 32 & \text { OxA-35182** } & \text { Roundwood } \\ 3340-3020 \text { BC } & 4466 \pm 32 & \text { OxA-35183** } & \text { Roundwood } \\ 7590-7380 \text { BC } & 8445 \pm 45 & \text { OxA-35184 } & \text { Roundwood } \\ 3940-3690 \text { BC } & 4995 \pm 32 & \text { OxA-35633 } & \text { Roundwood }\end{array}$

AD 1520-1800

$963 \pm 24$

$267 \pm 23$

$8091 \pm 38$

$4164 \pm 30$

$7815 \pm 37$

$4502 \pm 31$

$4490 \pm 31$

$4491 \pm 31$

$4316+32$

$4466 \pm 32$

$4995 \pm 32$
Prunus sp.

Prunus sp.

Pomoideae

Quercus sp.

Prunus sp.

Quercus sp.

Quercus sp.

Quercus sp.

Quercus sp.

Pomoideae

Pomoideae

Corylus avellana

Quercus sp.

Quercus sp.

Quercus sp.

Quercus sp.

Quercus sp.

(Continued)

\section{Research}




\begin{tabular}{|c|c|c|c|c|c|c|}
\hline \multicolumn{7}{|c|}{ Pillar recess } \\
\hline 119 & Deposit at base of recess & $2130-1900 \mathrm{BC}$ & $3629 \pm 29$ & OxA-31681 & Roundwood & Corylus avellana \\
\hline 119 & Deposit at base of recess & $\mathrm{AD} 1680-1940$ & $116 \pm 24$ & OxA-31866 & Roundwood & Corylus avellana \\
\hline \multicolumn{7}{|l|}{ Ditch } \\
\hline 128 & Upper ditch fill (west end) & 4530-4360 BC & $5619 \pm 34$ & OxA-35153 & Roundwood & Quercus sp. \\
\hline 171 & Middle ditch fill (east end) & $4910-4690$ BC & $5910 \pm 45$ & OxA-35396 & Roundwood & Calluna vulgaris \\
\hline \multicolumn{7}{|l|}{ Trench 2} \\
\hline \multicolumn{7}{|l|}{ Trench 3} \\
\hline 302 & Deposit in Trench 3 & AD 1190-1280 & $798 \pm 25$ & OxA-31867 & Roundwood & Calluna vulgaris \\
\hline
\end{tabular}

* OxA-31820 and OxA-31821 are samples from the same piece of Pomoideae charcoal.

** OxA-35182 and OxA-35183 are samples from the same piece of Quercus sp. charcoal. 
Carn Goedog are up to $4 \mathrm{~m}$ in length (Figure 4). Recesses in the face of this section of the outcrop reveal the locations from which pillars were taken; there is no trace of these pillars evident among the boulders and rubble at the foot of the outcrop. The fresh faces of those pillars that remain in situ in this part of the quarry contrast with the smoothed and weathered surfaces of the remainder of the Carn Goedog outcrop.

One recess is large enough for four or five $4 \mathrm{~m}$-long $\times 0.7 \mathrm{~m} \times 0.5 \mathrm{~m}$ pillars to have been removed from this part of the outcrop (Figure 5). At some point in the past, this recess was blocked by the detached top of a pillar falling in front of it. A $0.5 \mathrm{~m}$-deep deposit of sediment filling the bottom of the recess produced Corylus avellana charcoal dating to 2130-1900 cal BC $(3629 \pm 29 \mathrm{BP})$ and cal AD 1680-1940 (116 $\pm 24 \mathrm{BP})$ (Table 1). This indicates that, following removal of the pillar from the rock face, sediments have accumulated in the resulting recess since at least the Early Bronze Age.

Trench 1 was enlarged in 2015 and 2016 to reveal a series of features that may relate to prehistoric quarrying activity. At the southern foot of the outcrop, excavation revealed an artificial platform of flat slabs - many of them split—laid (with the split faces upwards) in a tongue-shaped formation $10 \mathrm{~m}$ north-south by at least $8 \mathrm{~m}$ east-west (Figure 6). Those slabs lying against the face of the outcrop had been pressed into the underlying sediments, presumably by the weight of pillars lowered onto the platform. Away from the outcrop, the platform terminates with a vertical drop of $0.9 \mathrm{~m}$ to the ground surface beyond. This platform is stratigraphically earlier than a series of deposits that included early modern quarrying debris and hearths of the Roman and medieval periods. One hearth (Figure 6: 105 ) set within a gap in the platform where a slab had been removed produced charcoal dating to $7190-6840 \mathrm{cal} \mathrm{BC}(8091 \pm 38 \mathrm{BP})$ and $2890-2630 \mathrm{cal} \mathrm{BC}(4164 \pm 30 \mathrm{BP})($ Table 1$)$. The earlier of these two pieces of charcoal, dating to the Early Mesolithic, is presumably residual, disturbed from layers beneath the platform when the slab was removed.

Charcoal from the buried soil on which the slabs rested and from soil in between the slabs produced six radiocarbon dates from the fourth millennium BC (see Table 1).

To the south of the platform, an $11 \mathrm{~m}$-long $\times 3 \mathrm{~m}$-wide $\times 0.4 \mathrm{~m}$-deep ditch (129) ran north-east to south-west (Figure 7). The sandy material dug out to create the ditch was derived from the iron-rich lower B, or spodic Bs, horizon material of a podzol, and was spread out in a $0.1 \mathrm{~m}$-thick deposit (161) extending for $4.5 \mathrm{~m}$ beyond the ditch's southern edgeeffectively becoming the 'new' Bs horizon of the subsequent podzol formation. The ditch itself was filled with closely packed rubble and large stones (some of megalithic proportions), rising $0.4 \mathrm{~m}$ above the top of the ancient ground's surface to form a barrier $2 \mathrm{~m}$ beyond the southern edge of the platform. Five pieces of charcoal from this stony fill produced Mesolithic dates (interpreted as residual in this redeposited ditch fill; Table 1), and a sixth charcoal sample dated to $3020-2880 \mathrm{BC}(4307 \pm 30 \mathrm{BP})$.

\section{Tools and quarrying techniques}

As the acidic podzolic soils of Carn Goedog prevent the preservation of organic materials, such as bone or antler, the only surviving artefacts are of stone. These include a large number of coarse stone tools, a handful of quartz flakes and a single chert blade. The most common of the coarse stone tools are implements with wedge-shaped profiles $(n=15)$, generally

(C) Antiquity Publications Ltd, 2019 


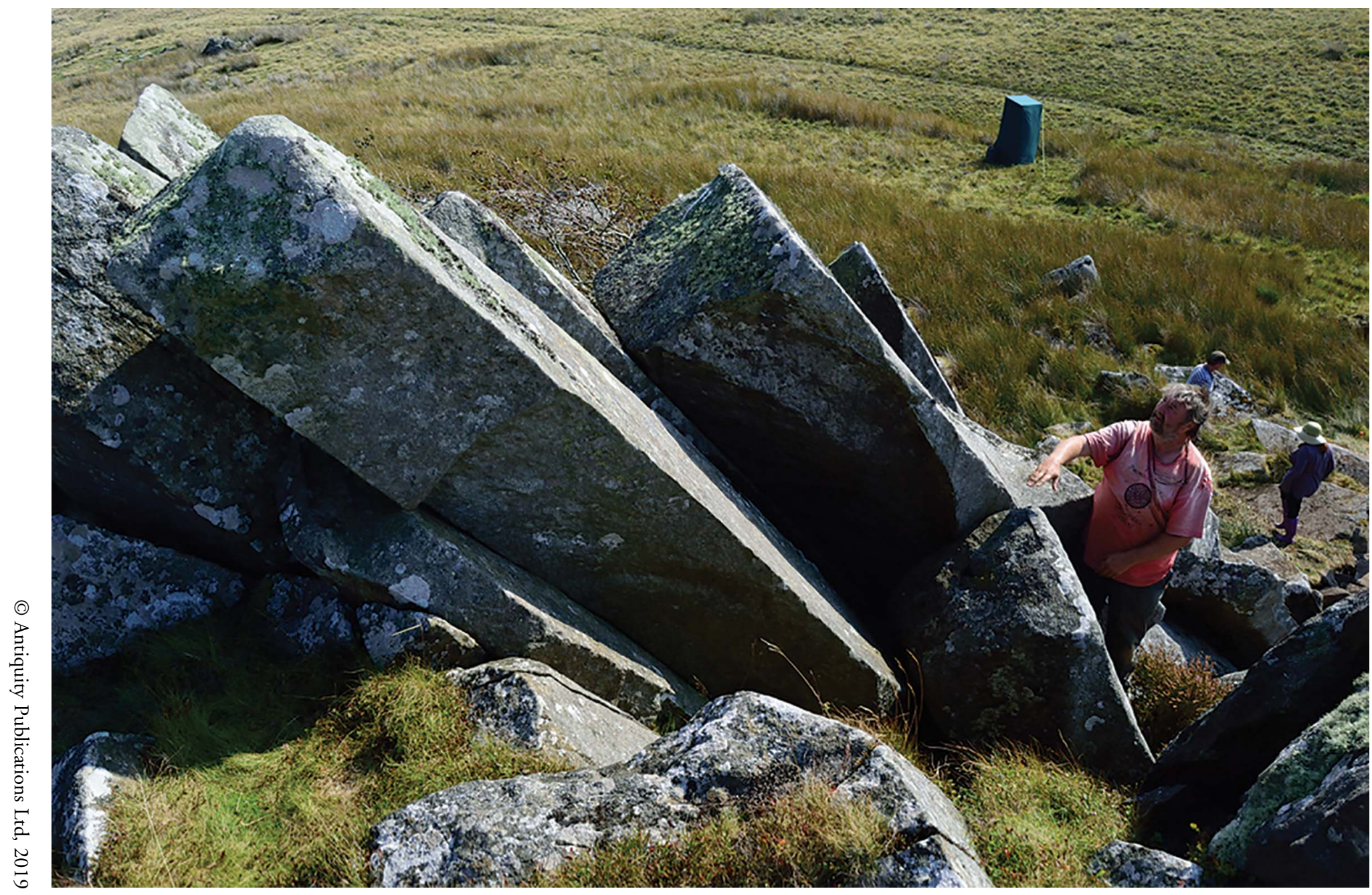

Figure 4. Unmodified in situ dolerite pillars at Carn Goedog, viewed from the north-west (photograph by Adam Stanford). 


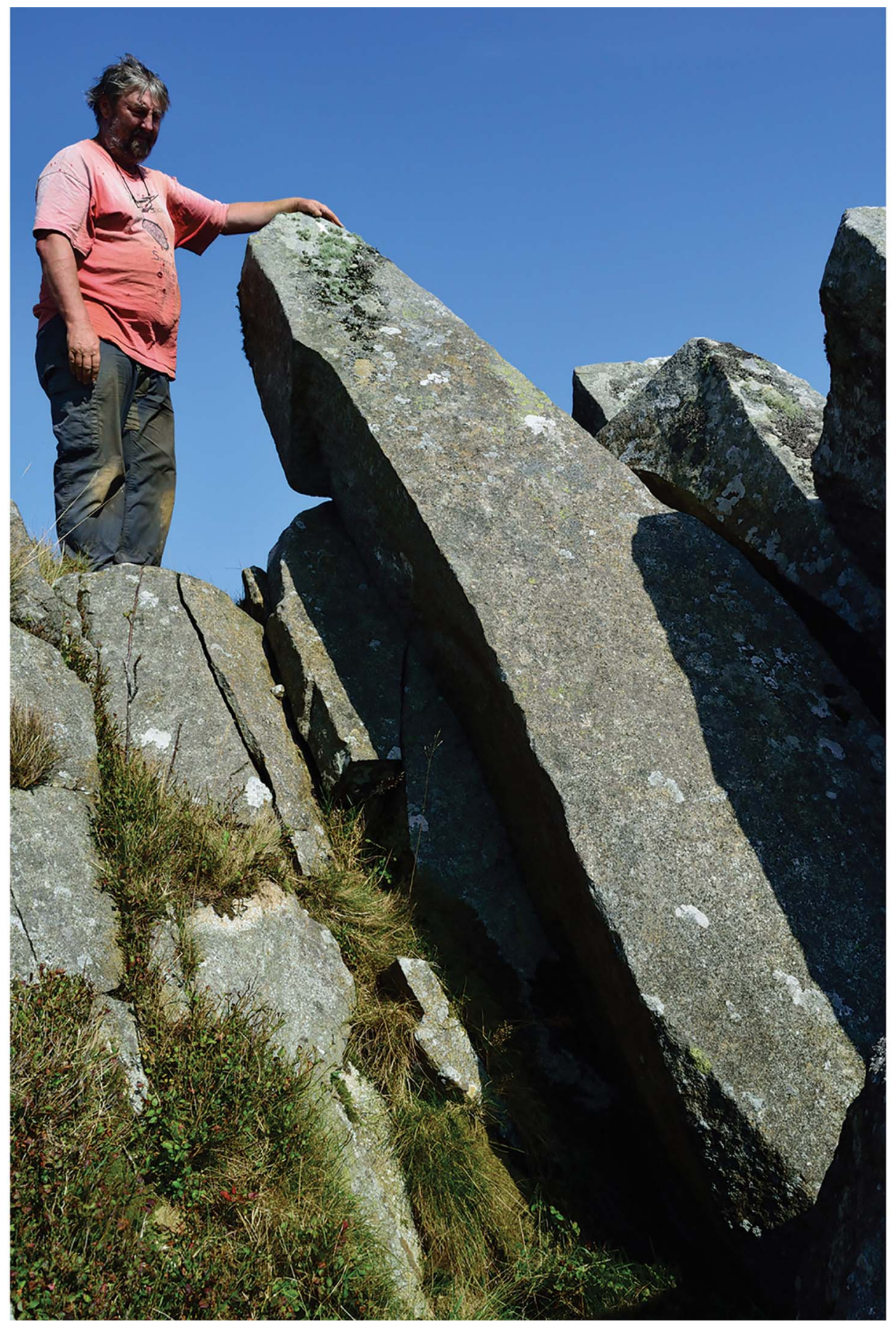

Figure 5. The large recess from which multiple pillars have been removed at Carn Goedog, viewed from the south (photograph by Adam Stanford).

(C) Antiquity Publications Ltd, 2019 


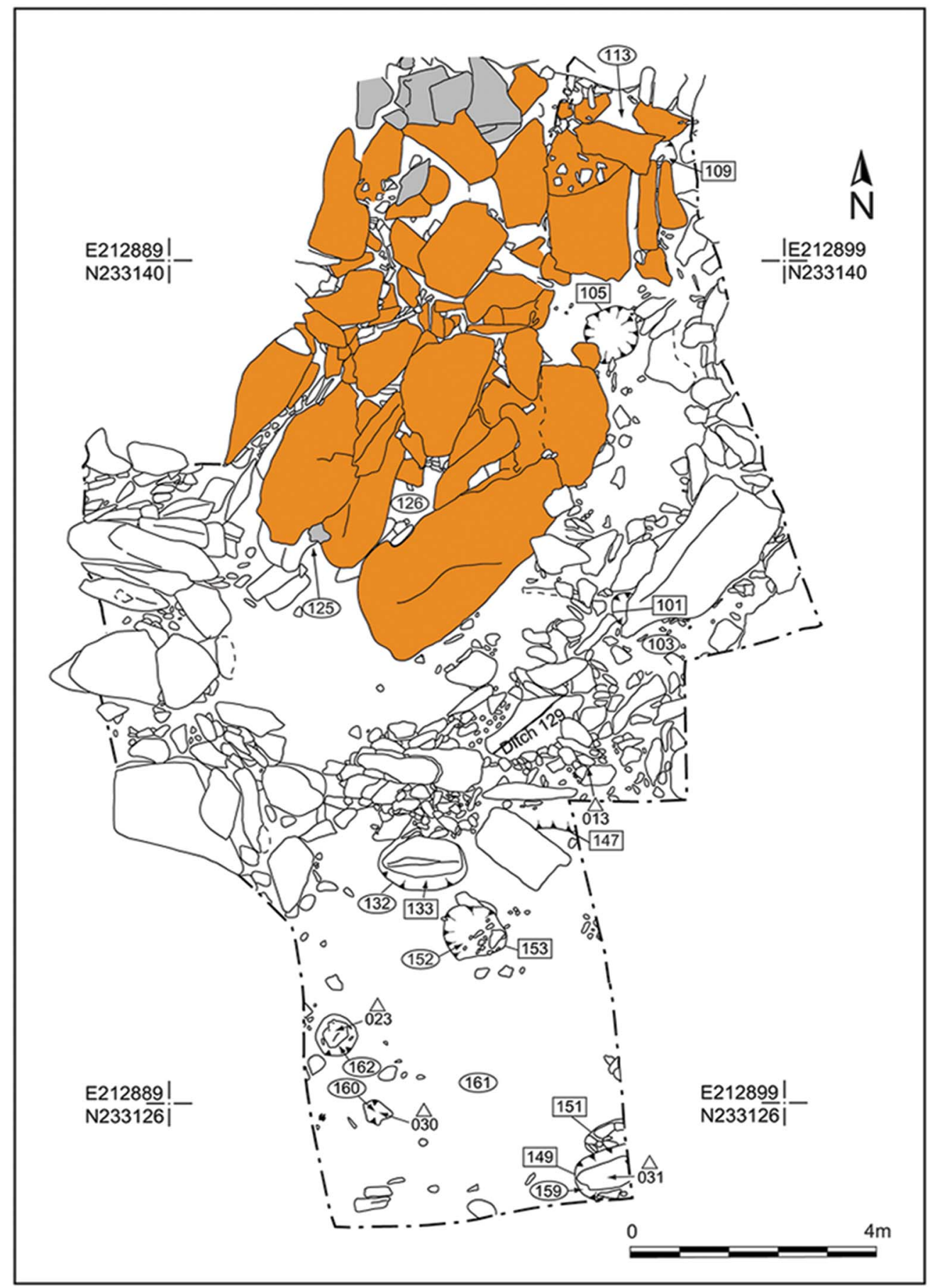

Figure 6. The Carn Goedog stone platform (shaded brown) and, to the south, the stone-filled ditch (129) running north-east to south-west (drawn by Irene de Luis). 


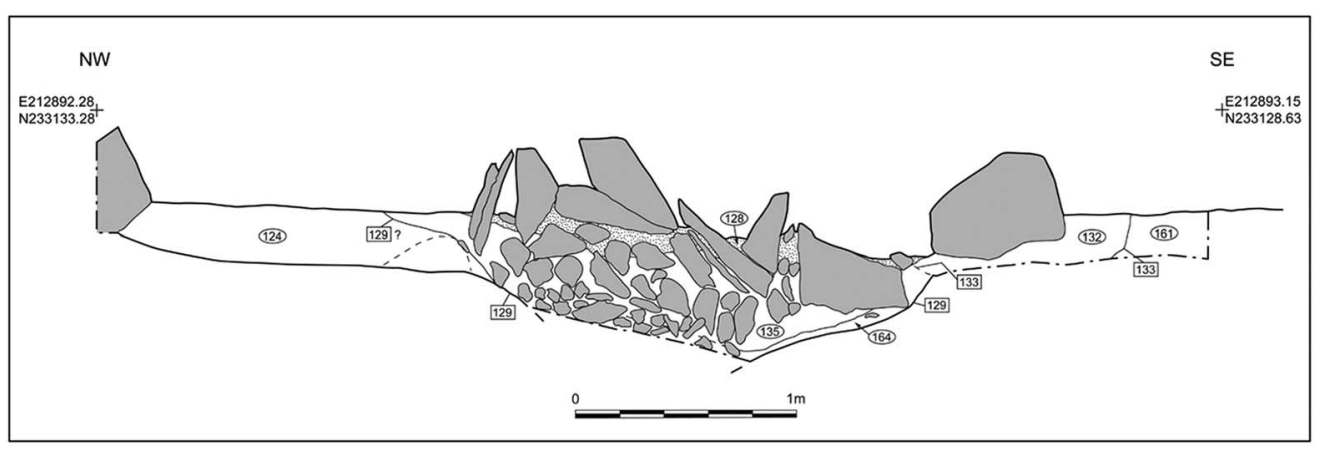

Figure 7. Section north-south through the stone-filled ditch (129) in front of the platform at Carn Goedog (drawn by Irene de Luis).

exhibiting a wide 'blade' at one end and a narrow, thick terminal at the other (Figure 8). These display numerous flake scars on the blade, along one or both sides of the tool. Some have traces of battering on their thick ends and there are also occasional scars running between the thick end and the blade.

These wedge-sectioned coarse stone tools are interpreted as wedges that were used for opening up the joints between each naturally formed pillar so that it could be levered away from the outcrop. These tools are all of mudstone or sandstone, rather than the local dolerite. This raises the possibility that they were used because of their softness in relation to the spotted dolerite. One reason for this may be that the forces created by driving in soft stone wedges would not have caused fractures within the dolerite, which might have weakened the pillars. Any fracturing would have been confined to the soft wedges rather than the monoliths.

Other coarse stone tools include a handaxe-like implement with battering along its edges. Such a tool could have been used to open up narrow joints, by widening the sides of the joint sufficiently for a wedge to be then inserted and driven in. Two such examples of joint-widening were recorded on the outcrop, where a stone tool has been used to create a narrow hollow (Figure 9). Slight hollows on the edges of in situ pillars are suspected to be the remaining halves of such features, where the other half has been removed with a pillar.

The presence of wedges indicates the basic quarrying technique; although both stone and wooden wedges may have been employed, no wooden artefacts have survived at Carn Goedog. Ethnographic observations of monolith extraction (e.g. Hoskins 1986; Steimer-Herbet 2012) reveal the considerable extent to which organic materials—ropes, planks, timbers and wooden tools, such as wedges and mallets - are used in such quarrying operations. The use of these materials can, however, only be surmised in an archaeological context where organic remains do not survive.

The position of the stone platform at the base of the outcrop gives some idea of the probable sequence of pillar removal. Once a pillar was loosened from the rock face using wedges, ropes could be secured around its upper section so that it could be pulled outwards from the rock face, being steadied by ropes held by workers standing on the wide, level summit of the outcrop. Those on top of the outcrop could have carefully payed out their ropes to control the pillar's descent so that it slowly pivoted down onto the artificial platform,

(C) Antiquity Publications Ltd, 2019 

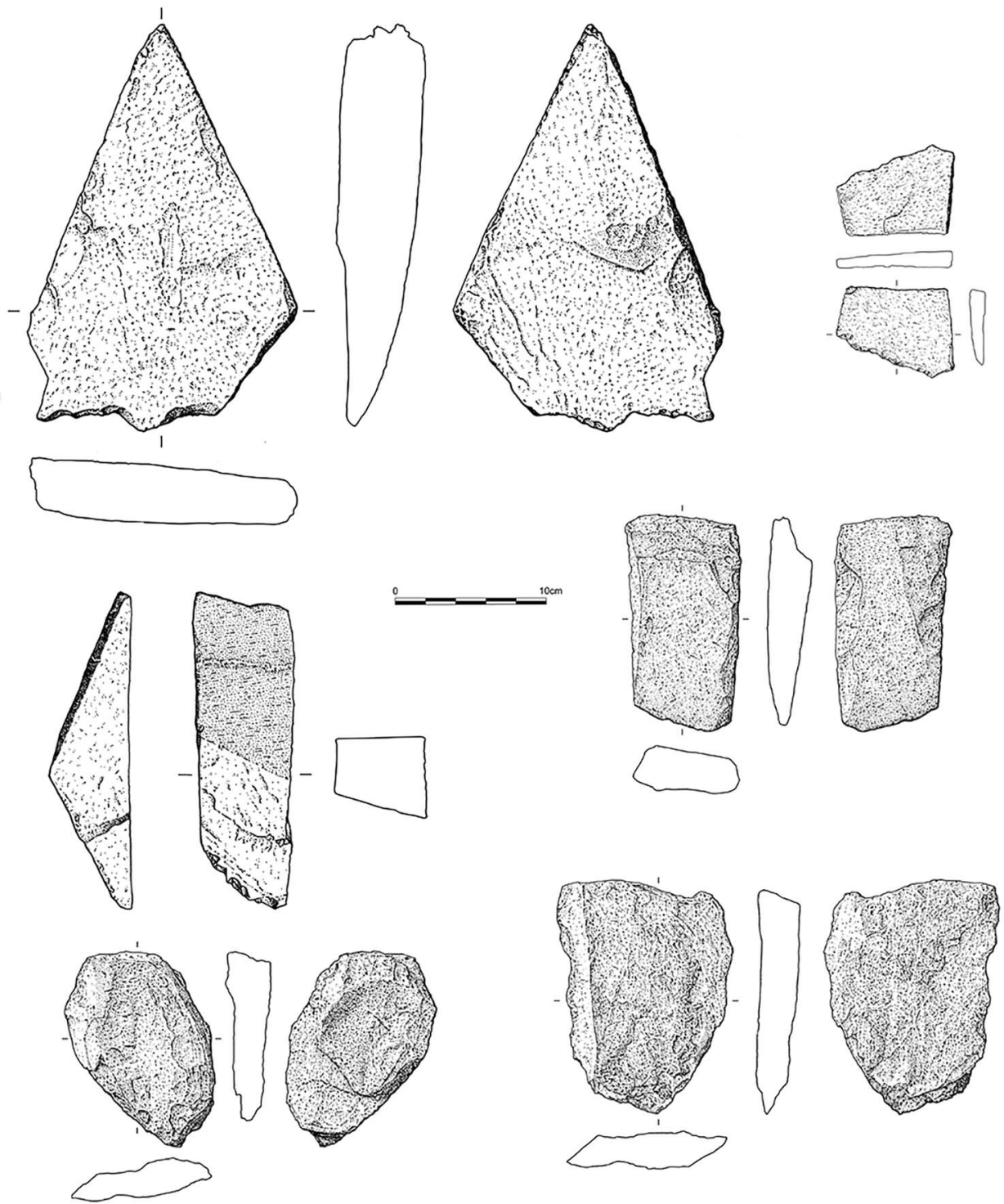

Figure 8. Stone wedges and a hammerstone (bottom left) from Neolithic contexts at Carn Goedog (drawn by Irene de Luis).

its tip pressing some of the platform's stone slabs deep into the soil beneath. Ropes could then be reattached to lower the pillar to a horizontal position on the platform.

Timbers could have been laid on top of the platform, as seen in present-day megalith-quarrying in Indonesia (Steimer-Herbet 2012). These would have facilitated movement of the pillar, using long wooden levers, to the platform's outer edge. The pillar could then have been lowered onto a wooden sledge and hauled away with ropes. The ditch, when open and with its rubble fill, would

(C) Antiquity Publications Ltd, 2019 


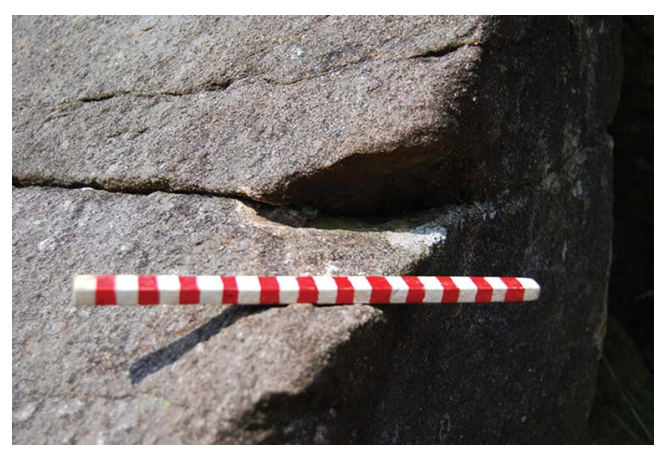

Figure 9. Widening of a joint between pillars at Carn Goedog, viewed from the south (photograph by Duncan Schlee). have blocked the movement of pillars from the platform and the outcrop and therefore may have been dug to decommission the quarry.

There is no evidence at Carn Goedog of any prepared surface or trackway leading away from the edge of the platform, and it is probable that the natural grassed surface would have sufficed. The geologist O.T. Jones (1966) records a local informant remembering their father dragging Preseli pillars to be used as gateposts across grass scorched after a long drought; dry turf, grass and heather would have formed a suitably slippery surface in prehistory. This ethnographic report is potentially a good analogy for prehistoric stone-moving, as the many dolerite gate-posts in the area today are of equivalent size to Stonehenge's bluestones.

\section{Megalith-quarrying at Carn Goedog and Craig Rhos-y-felin}

At least five bluestone pillars (stones 33, 37, 49, 65, 67) were taken from Carn Goedog, and probably many more (Bevins et al. 2013). The multiple and large recesses in the rock face are further evidence that Neolithic pillar removal was extensive at this outcrop, even though quarrying in the early modern period has obscured evidence of earlier pillar removal in the western part of the outcrop. In contrast, the bluestone rhyolite quarry at Craig Rhos-y-felin appears to have been used much less intensively during the Neolithic (Parker Pearson $e t$ al. 2015). At least one pillar was taken from this rhyolite source, but probably no more than two or three in total.

Although pillar extraction at Craig Rhos-y-felin was more limited, its quarrying structures are similar to those at Carn Goedog. An artificial platform was also constructed here, its vertical outer edge formed by a drystone retaining wall (Parker Pearson et al. 2015: 1344, fig. 12). This wall was built on top of alluvial sediment containing charcoal dating to the sixth millennium BC. Beyond the wall, a $2 \mathrm{~m}$-wide hollow way (a trackway eroded by footfalls), cut into this soft riverine sediment, led from the foot of the wall away from the quarry (Parker Pearson et al. 2015). The hollow way and the foot of the revetment wall were covered by a $0.2-0.35 \mathrm{~m}$-deep layer of charcoal-rich alluvium. New radiocarbon dates from this later sediment (reported here for the first time; see Table 2) indicate that the Craig Rhos-y-felin hollow way went out of use by the end of the last quarter of the fourth millennium BC. The dates from this alluvial fill hint at episodic vegetation clearance and associated soil erosion upstream during this period of the Middle Neolithic. Consistent with a Neolithic date is a rhyolite endscraper from the platform fill (Figure 10); the only dateable charcoal from this fill is from the sixth to fifth millennia BC (Table 2) and is probably residual in this redeposited material.

The dating evidence from the bluestone quarry sites at both Carn Goedog and Craig Rhos-y-felin arguably places monolith extraction in the second half of the fourth millennium BC. Most of the prehistoric dates for Carn Goedog fall within the period (C) Antiquity Publications Ltd, 2019 
Table 2. Further radiocarbon dates from Craig Rhos-y-felin (additional to those in Parker Pearson et al. 2015). Calibrated dates are given at $\mathbf{9 5 . 4 \%}$ probability (Bronk Ramsey 2009; Bronk Ramsey \& Lee 2013).

\begin{tabular}{llclll}
\hline & Date cal & Date & Sample & & \\
Context & BC/AD & BP & number & Material & Species \\
\hline
\end{tabular}

Fill of the platform behind the revetment wall

\begin{tabular}{lccccc}
164 & $5226-5011 \mathrm{BC}$ & $6182 \pm 35$ & OxA-35149 & Roundwood & Tilia sp. \\
164 & $4907-4723 \mathrm{BC}$ & $5940 \pm 33$ & OxA-35150 & Roundwood & Corylus avellana \\
Alluvium filling the hollow way and against the revetment wall face & \\
152 & $3330-2920 \mathrm{BC}$ & $4434 \pm 31$ & OxA-35151* & Roundwood & Corylus avellana \\
152 & $3520-3340 \mathrm{BC}$ & $4627 \pm 34$ & OxA-35412 & Roundwood & Corylus avellana \\
152 & $3270-2910 \mathrm{BC}$ & $4404 \pm 31$ & OxA-35152* & Roundwood & Corylus avellana \\
\hline
\end{tabular}

* OxA-35151 and OxA-35152 are samples from the same piece of Corylus avellana charcoal.

c. 3350-3000 cal BC, while those for Craig Rhos-y-felin provide a slightly longer chronological span. The latest date from the platform at Carn Goedog is very close to the Neolithic date from the blocking ditch; together, they indicate that the monolith quarry went out of use in or around the thirtieth century cal BC. These dates coincide closely with that of 3080-2890 cal BC (at 95\% confidence; 4332 \pm 35 BP) from cremated human bone in an inferred primary fill of Aubrey Hole 32 at Stonehenge (Parker Pearson et al. 2009: 26, tab. 2). The Aubrey Holes are a circle of Late Neolithic pits inside the circuit of Stonehenge's outer bank, associated with its stage 1 construction (Darvill et al. 2012a; Parker Pearson 2012: 181-86). Our recent reassessment of these 56 pits interprets them as being sockets for the bluestones on their arrival at Stonehenge (Parker Pearson et al. 2009: 32; Darvill et al. 2012a: 1029), and this coincidence of dates is therefore particularly striking. The fact that the stone-filled ditch formed a barrier that prevented further monoliths from being removed from the Carn Goedog quarry-within a century or less of the bluestones being moved to Stonehenge-raises interesting questions about access to and control of this outcrop and its products.

\section{From the bluestone quarries to Stonehenge}

In which directions did stone-dragging teams move the monoliths on leaving the quarries? At Craig Rhos-y-felin, the hollow way from the platform leads northwards, in the opposite direction to the Preseli Hills and Stonehenge. Yet tributary valleys downstream could have been used to haul monoliths out of this steep-sided valley and onto the higher ground of the plateau at the foot of the Preselis. At Carn Goedog, the direction of movement out of the quarry is less certain. Monoliths could have been dragged downhill to the west of the outcrop, where the stone-free slope provides a clear route down to the same plateau. Alternatively, monoliths could have been pulled south-westwards, up a slight incline (now the route of a post-medieval trackway over the summit of Preseli). Once on the top of the Preseli ridge, monoliths could have been moved westwards along the spine of the hills, past the unspotted dolerite source of Cerrigmarchogion and Craig Talfynydd. 


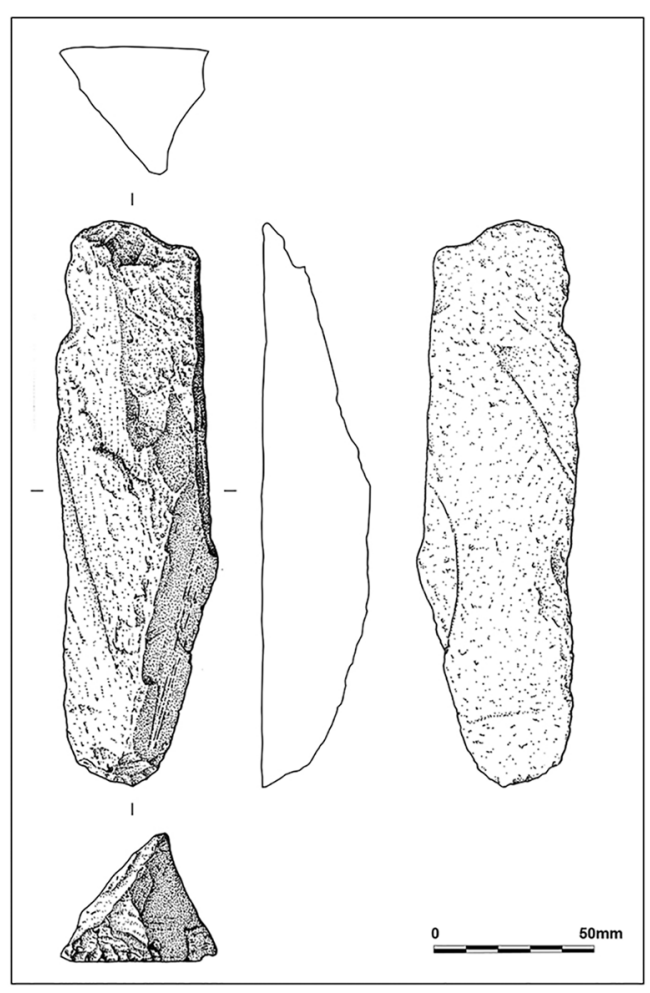

Figure 10. A rhyolite end-scraper from the fill of the platform at Craig Rhos-y-felin (drawn by Irene de Luis).
This route westwards along the top of the Preseli ridge passes within $2 \mathrm{~km}$ of an Early Neolithic causewayed enclosure at Banc Du-the only one so far confirmed in west Wales-on a promontory to the south of the ridge. Excavation of the Banc Du enclosure's inner ditch in 2005 revealed that it was initially dug in 3610 3515 cal BC and was recut in 31052915 cal BC (Darvill et al. 2005: 22-23; 2007; Whittle et al. 2011: 526-27; Darvill \& Wainwright 2016: 75-76). This latter date broadly coincides with the end of megalith-quarrying at Carn Goedog and the erection of bluestones in the Aubrey Holes at Stonehenge. It suggests that Banc Du's inner enclosure (approximately $200 \times 150 \mathrm{~m}$ ) was renewed and reused at this time.

Might the Banc Du enclosure, with its extensive views across south-west Wales as far as the isle of Lundy in the Bristol Channel, have been a stopping place for the bluestones? Might they even have been erected here as a large stone circle?

Although this is certainly possible, the current evidence indicates that uprights set within the bank were of timber and not stone (Darvill et al. 2005: 22-23, fig. 7, 2007; Darvill \& Wainwright 2016: 75-76). In addition, a high-resolution magnetometer survey within and around the enclosure failed to reveal evidence of any probable cultural features, other than the enclosure ditches and banks (Darvill et al. 2012b). That said, the poor magnetic ground conditions at Banc Du are "not especially conducive to geophysical survey" (Darvill et al. 2012b: 40).

The Banc Du causewayed enclosure lies $6 \mathrm{~km}$ south of an unusually dense concentration of other Early Neolithic monuments in the lower Nevern Valley (Figure 2) that includes portal dolmens and a palisaded enclosure at Dryslwyn (Lynch 1972; Barker 1992; Darvill \& Wainwright 2016: 76; Timothy Darvill pers. comm.). The late fourth-millennium BC dates on charcoal from the alluvium at Craig Rhos-y-felin hint at Middle Neolithic activity in the upper reaches of the Nevern Valley. One or more monuments within which the bluestones were first erected may, therefore, have been located in the headwaters of the River Nevern and its tributaries. The idea that these stones were first erected as a circle in the locality of their quarry sources is not a new one (Parker Pearson 2016; Parker Pearson et al. 2016). Almost 100 years ago, the geologist H.H. Thomas speculated that the bluestones had initially been incorporated into a "venerated stone circle" somewhere in Preseli, before making their momentous journey to Salisbury Plain (Thomas 1923: 258). Around the same time, (C) Antiquity Publications Ltd, 2019 
surveyors from the Royal Commission on Ancient and Historical Monuments (RCAHM) in Wales (1925) recorded the presence of a partial stone circle at Waun Mawn, perched above the source of a tributary of the River Nevern. This is located just $3 \mathrm{~km}$ west of Carn Goedog and Craig Rhos-y-felin, $2 \mathrm{~km}$ north-west of Cerrigmarchogion and $3 \mathrm{~km}$ north-east of Banc Du. Yet no one-either at the time or subsequently-has investigated whether Waun Maun might be this former stone circle-potentially the original Stonehenge.

Subsequent researchers such as Grimes (1963: 149-50) were unconvinced by the RCAHM's identification of Waun Mawn's stones as the remnants of a stone circle. Furthermore, they considered that any such former bluestone monument should lie on the south side of Preseli, below Carn Menyn, the outcrop that was for so long considered to be the main source of the bluestones. Now that several sources have been identified on the north side of Preseli, we are turning our attention to Waun Mawn.

\section{Acknowledgements}

We thank the landowners, the Barony of Cemaes (land agents David Cole and Kathryn Perkins) for allowing our excavations at Carn Goedog. Consent to work within this Site of Special Scientific Interest was granted by Cyfoeth Naturiol Cymru (Natural Resources Wales). The staff of the Pembrokeshire Coast National Park are especially thanked for their assistance, particularly Delun Gibby, Richard Vaughan and Geraint Harries-we also owe a debt of gratitude to the late Phil Bennett, the former National Park archaeologist. Huw and Dilys Davies kindly allowed us to carry out excavations at Craig Rhos-y-felin and to use their farmyard for flotation of soil samples. We also thank Dylan Thomas Cranes for use of mechanical excavators at Craig Rhos-y-felin. Research was funded by grants from the Society of Antiquaries and the Royal Archaeological Institute (in 2014), the National Geographic Society (in 2015) and the British Academy and the Cambrian Archaeological Association (in 2016). The NERC radiocarbon panel awarded radiocarbon dates for the project in 2014-2017. We thank Derek Hamilton of SUERC for consultation on those radiocarbon dates and Rhian Kendall of the British Geological Survey for providing the geological information in Figure 1. We also thank the two anonymous reviewers for their helpful and incisive comments.

\section{References}

AtKinson, R.J.C. 1956. Stonehenge. London: Hamilton.

BARKER, C.T. 1992. The chambered tombs of south-west Wales: a reassessment of the Neolithic burial monuments of Carmarthenshire and Pembrokeshire. Oxford: Oxbow.

Bevins, R.E., R.A. Ixer \& N.G. Pearce. 2013. Carn Goedog is the likely major source of Stonehenge doleritic bluestones: evidence based on compatible element geochemistry and principal components analysis. Journal of Archaeological Science 42: 179-93. https://doi.org/10.1016/j.jas.2013.11.009

Bronk Ramsey, C. 2009. Bayesian analysis of radiocarbon dates. Radiocarbon 51: 337-60. https://doi.org/10.1017/S0033822200033865

Bronk Ramsey, C. \& S. Lee. 2013. Recent and planned developments of the program OxCal.
Radiocarbon 55: 720-30. https://doi.org/10.1017/S0033822200057878

Darvill, T. \& G.J. Wainwright. 2016. Neolithic and Bronze Age Pembrokeshire. Prehistoric, Roman and early medieval Pembrokeshire. Pembrokeshire County history volume I: 55-222. Haverfordwest: Pembrokeshire County History Trust.

Darvill, T., D. Morgan Evans, R. Fyfe \& G.J. Wainwright. 2005. Strumble-Preseli Ancient Communities and Environment Study (SPACES): fourth report 2005. Archaeology in Wales 45: 17-23.

Darvill, T., R.V. Davies, D. Morgan Evans, R.A. Ixer \& G.J. Wainwright. 2007.

Strumble-Preseli Ancient Communities and Environment Study (SPACES): fifth report 2006. Archaeology in Wales 46: 100-107.

Darvill, T., P. Marshall, M. Parker Pearson \& G.J. Wainwright. 2012a. Stonehenge

(C) Antiquity Publications Ltd, 2019 
remodelled. Antiquity 86: 1021-40.

https://doi.org/10.1017/S0003598X00048225

Darvill, T., G.J. Wainwright, F. LÜth \&

N. MülLER-SCHEesSEL. 2012b. Strumble-Preseli Ancient Communities and Environment Study (SPACES): seventh report 2009-11. Archaeology in Wales 51: 27-44.

Grimes, W.F. 1963. The stone circles and related monuments of Wales, in I. Foster \& L. Alcock (ed.) Culture and environment: essays in honour of Sir Cyril Fox: 93-152. London: Routledge \& Kegan Paul.

Hoskins, J. 1986. So my name shall live: stone-dragging and grave-building in Kodi, west Sumba. Bijdragen tot de Taal-, Land-en Volkenkunde 142: 31-51. https://doi.org/10.1163/22134379-90003367

Ixer, R.A. \& R.E. Bevins. 2011. Craig Rhos-y-felin, Pont Saeson is the dominant source of the Stonehenge rhyolitic 'debitage'. Archaeology in Wales 50: 21-31.

- 2016. Volcanic group A debitage: its description and distribution within the Stonehenge landscape. Wiltshire Archaeological and Natural History Magazine 109: 1-14.

IXer, R.A. \& P. Turner. 2006. A detailed re-examination of the petrography of the Altar Stone and other non-sarsen sandstones from Stonehenge as a guide to their provenance. Wiltshire Archaeological and Natural History Magazine 99: 1-9.

IXer, R.A., R.E. Bevins \& A.P. Gize. 2015. 'Volcanics with sub-planar texture' in the Stonehenge landscape. Wiltshire Archaeological and Natural History Magazine 108: 1-14.

IXer, R.A., P. Turner, S. Molyneux \& R.E. Bevins. 2017. The petrography, geological age and distribution of the Lower Palaeozoic sandstone debitage from the Stonehenge landscape. Wiltshire Archaeological and Natural History Magazine 110: 1-16.

Jones, O.T. 1966. Cerrig Llwydion Carn Meini. $Y$ Gwyddonydd 4: 215-20.

KeLLAWAY, G.A. 1971. Glaciation and the stones of Stonehenge. Nature 232: 30-35. https://doi.org/10.1038/233030a0

LynCH, F.M. 1972. Portal dolmens in the Nevern Valley, Pembrokeshire, in F.M. Lynch \& C. Burgess (ed.) Prehistoric man in Wales and the west: 67-84. Bath: Adams \& Dart.
Parker Pearson, M. 2012. Stonehenge: exploring the greatest Stone Age mystery. London: Simon \& Schuster.

-2016. Secondhand Stonehenge? Welsh origins of a Wiltshire monument. Current Archaeology 311: $18-22$.

Parker Pearson, M., A. Chamberlain, M. Jay, P. Marshall, J. Pollard, C. Richards, J. Thomas, C. Tilley \& K. Welham. 2009. Who was buried at Stonehenge? Antiquity 83: 23-39. https://doi.org/10.1017/S0003598X00098069

Parker Pearson, M., R. Bevins, R. Ixer, J. Pollard, C. Richards, K. Welham, B. Chan, K. Edinborough, D. Hamilton, R. MacPhail, D. Schlee, J.-L. Schwenninger, E. Simmons \& M. Sмith. 2015. Craig Rhos-y-felin: a Welsh bluestone megalith quarry for Stonehenge. Antiquity 89: 1331-52. https://doi.org/10.15184/aqy.2015.177

Parker Pearson, M., J. Pollard, C. Richards, D. Schlee \& K. Welham. 2016. In search of the Stonehenge quarries. British Archaeology 146: 16-23.

Royal Commission on Ancient and Historical Monuments in Wales. 1925. An inventory of the ancient monuments in Wales and Monmouthshire. Volume VII, County of Pembroke. London: HMSO.

Steimer-Herbet, T. 2012. Sumba: l'île des megaliths modernes. Archéologia 495: 36-45.

Thomas, H.H. 1923. The source of the stones of Stonehenge. Antiquaries Journal 3: 239-60. https://doi.org/10.1017/S0003581500005096

Whittle, A.W.R., F. Healy \& A. Bayliss. 2011. Gathering time: dating the Early Neolithic enclosures of southern Britain and Ireland. Oxford: Oxbow.

Williams-Thorpe, O., C.P. Green \& J.D. SCOurSE. 1997. The Stonehenge bluestones: discussion, in B. Cunliffe \& C. Renfrew (ed.) Science and Stonehenge: 315-18. London: British Academy.

Williams-Thorpe, O., M.C. Jones, P.J. Рotts \& P.C. Wевв. 2006. Preseli dolerite bluestones: axe-heads, Stonehenge monoliths, and outcrop sources. Oxford Journal of Archaeology 25: 29-46. https://doi.org/10.1111/j.1468-0092.2006. 00247.x

Received: 1 February 2018; Revised: 1 June 2018; Accepted: 5 June 2018

(C) Antiquity Publications Ltd, 2019 